\title{
Italy, Secret Treaty of London and the Albanian Issue
}

\author{
Xhilda Shuka \\ Institute of History, University Centre of Albanological Studies, Tirana, Albania \\ Email:xhildashuka@yahoo.com
}

\section{Doi:10.5901/ajis.2016.v5n2p219}

\begin{abstract}
Through this work we aim to analyze the Italian attitude towards the Albanian state at the beginning of the XX century, based on the treatment of the Secret Treaty of London in May 1915. This treaty synthesised the Italian policy towards the newly established Albanian state, during one of the most difficult periods of Europe, the First World War. Newly established Albanian state with its truncated borders of the London Conference in 1913, deserved to have at least the support of the overseas neighbor, Italy, and this would bring friendship and mutual interest. But Italy although an affirmed world power, failed to rise beyond an shortsighted and imperialist interest versus Albania, aiming through this treaty to divide Albanian lands with other treacherous neighbors, and eventually disappear the descendants of the great Skanderbeg, of Pyrrhu, Ali Pasha, the Great Kostandin, the ancient Pellazgo- Illyrians.
\end{abstract}

Keywords: the secret Treaty of London, World War I, Antanta, Italy

\section{Introduction}

Albania today is the product of a great war for national survival. Surrounded by neighbors with a less friendly orientation in the course of history, to Italy, Albania has seen a window to western civilization, always even in the darkest periods of its history. The grand strategist Scanderbeg was connected to a sincere friendship with Italian princes, being assembled alongside them in support of his soldiers, but also waiting from them support to the exemplary resistance against the Ottoman Empire. Not coincidentally, after his death Albanians migrated and settled in the Italian lands and not elsewhere, creating the Arberesh community that even today retains their language and ancestral traditions. This friendship evolving over centuries should be fed continuously with mutual work and supporting facts. But despite the fact that the London Conference (1913) "desfigured" the Albanian nation p by disconnecting a large part of the ethnic territory, the neighboring countries together with Italy aimed the total destruction of the Albanian state, during the First World War. Their idea was conceived as a strategy from the design of the Secret Treaty of London (1915), among the countries of the Antanta and Italy. Based on this context we intend to take with this work further light, to understand and deepen better and more Italian stance towards the Albanian issue in World War I, and especially the Secret Treaty of London. Naturally arises discussion on the reasons and consequences of this attitude, the discussion that we have tried to harness based on historical facts of the literature. As for the other countries neighboring Albania during those years, such as Greece, Serbia and Montenegro, chauvinist policy toward Albania was understandable in the sense that the injustice of 1913 that were made to the Albanian lands, can not be justified except with new injustices but for Italy the question is why should they assume such a position to Albania?

There are designed and written works in the field of historiography, within and outside the country regarding the Italian policy towards the Albanian issue during World War I, but in this paper we try to understand and shed more light on the reasons and consequences of this attitude, see in a balanced point of view. The novelty of this work lies in the way of interconnected reflection, the internal and external, current and historical facts that led to the Italian attitude toward the Albanian issue in that period. Analysis of this attitude leads to the currently valid conclusions for the Italo-Albanian relations.

For the realization of this paper it is used the literature selected by major institutions on historical sources as the National Library of Albania, Albanian Central State Archive, the Library of the Academy of Sciences of Albania, the Library of the Institute of History of Albania. The literature consists of primary historical sources, such as manuscripts and the dailies of that period, memories of historical persons of the respective period, as well as secondary sources: historical publications and the most significant scientific articles about this issue. 


\section{Italy and World War I}

The beginning of World War I in 1914 found Italy in a neutral position. It had previously been a member of the Triple Alliance in a block with Germany and Austro-Hungary (Albanian issue in international acts (1867-1912), V. I, d. nr.30 pp. 296-299). But because of contradictions between Italy and Austria-Hungary this alliance could not be seen as "natural". With the onset of war Italy was not relocated to the side of Germany and Austro-Hungary configuring separation. It could not join in a war that Germany and Austro-Hungary had begun against other Powers headed precisely by England, which conflicted with the old provisions (1882) of the Triple Alliance. According to the Austro-Italian agreement of parity in the Balkan Peninsula, in December 1909, Austria-Hungary had to make aware Italy for the war against Serbia; which they did not execute, creating a legal basis for Italy to withdraw from the Triple Alliance and to reserve to play in the international plan the role of a great independent power.

On April 26, 1915, France, Britain and Russia (grouping of Antanta) concluded a deal with Italy, the secret Treaty of London, so that Italy entered the war alongside them. Italy had set as a condition the fulfillment of certain strong requirements; among other things, they wanted all the Dalmatian coast of Croatia, most of the Istrian peninsula, as well as important territories from Albania (Andelman, 2008, p.214).

Only a month after the signing of this treaty Italy sided with her military forces alongside the Antanta group.

This designation stems from the Treaty of London, because here were held negotiations on the terms of participation of Italy in World War I. There was signed the relevant treaty, too, and also in London was made the decision by all the signatories, to keep secret the contents of the treaty (Çami, 2007, pp.59-60). Antanta's powers engage to support at the end of the war, political and territorial claims of the Italian government of the time, listed in the Treaty.

Pact of London was a secret agreement concluded between the Antanta's Powers and Italy to meet the claims of the latter on the Dalmatian coast in general and expansionist designs in Albania in particular, taking into account the chauvinist desires of Serbia, Montenegro and Greece. According to item 5 of the Treaty, the Albanian coast of the outpouring of Buna to the loss of Drini in Shëngjin was supposed to be part of Serbia and Montenegro, in paragraph 6 it was determined that Vlora and Sazan would be part of Italy, according to paragraph 7 Italy could not oppose the desire of England, France and Russia to give Serbia and Montenegro the noth part of Albania and Greece the southern part, while in the Centre would be created an "autonomous" Albanian state that would be under the auspices of Italy. Among these requirements we can notice the Italian expansionist greed for setting Vlora and its province under the Italian sovereignty, and this was a greed which allowed the devision of the territory of the Albanian state of 1913 (Çami, 2007, p.60). Austrian party, members of the Old Triple Alliance together with Italy considered the involvement of Italy in the war alongside the Antanta, as a "betrayal". Even so it posed the question how it was possible for a country that for 15 years followed a foreign policy of reconciliation, quite unprepared for war, immediately decided to participate in it. Italian people in general did not like war, they did not want the measures affected by the Socialists and Catholics, the majority of Parliament did not like this, Giolotti, the politician with more prestige, whom some labeled as sold to the Germans, didn't want this too (Procacci, 2000 pp.494-495).

The camp of "pro-war" that included eminent names: like Albertini, director of the newspaper "Corriere della sera", Caesarea Baptist, socialist from Trento, Bisolatit, Salvemini, Gabriele D'Annunzio that held warmongering fiery speeches, and most recently, Benito Mussolini. This man, the most blatant recruit of Italian interventionist policy, had abandoned the Socialist Party in November 1914 and had established a newspaper of its own, "Popolo d'Italia", pages of which, preaching the resilience and revolutionary virtues of war. Crowds of students were encouraged in their "pro war" manifestations because the government and the court had already decided to exploit them to give the connotation of popular will to the decision that they had taken with the signing of the Treaty of London without the knowledge of Parliament and the country. Giolotti itself that was the most pessimists acknowledged that the war would not last three months, but three years. Perhaps the decisive element was the belief that a short and victorious war, with the establishment of a greater discipline in the country, will facilitate the evolution of an authoritarian state, which would give up the conservative forces of order in force and would clear the subversive threats. Therefore entry into the war was - one might even say, especially - a domestic policy action, some small handful of state barely dressed with legal forms. Giving full powers to the government was voted out in parliament by a very large majority, but it was only a Parliament, put under government's pressure and which had already lost his freedom. Perhaps seeing the internal consequences of entering into war, Giolotti, in May 1915, gave up from following up on his battle for any bias (Procacci, 2000 pp.495-497).

Both Blocks accelerated to use Albania each for themselves, and as a subject of their own military and political plans. Austro-Hungary, avoiding commitments taken at the London Conference on neutrality of the new state exerts pressure on Prince Vilhelm Vidi, in order for Albania to enter the conflict as an ally of the Central European empires. 
Response of Vienna, which removes any financial support to the prince, pushing the latter to leave Albania together with his Cabinet (September 1, 1914), while Austro-Hungary, to conquer Albanian lands under the pretext of "autonomy of Albania".

Inside the country, the picture was bleaker, in the sense of great division, in central Albania were operating the groups of Haxhi Qamili, who aspired to return the Turkish. Esat Pasha was soldier of everyone except Albania, undermining the Albanian legitimate authority to decide the state power. Southern Albania was terrorized by "VorioEpirus"Greek gangs. Except Kosovo, Serbs sought the security zone in north placing their troops even inside Albanian territory. Montenegro aimed Shkodra by all means. While Korca region declared autonomy under French people who could make gifts this vessel of Albanian territories, according to their interest. Bulgarians stand ready to take any part of eastern Albania.

It was created a favorable international situation for the neighboring countries who coveted the territory of Albania, which was used at the beginning by the government of Rome and that of Athens. While neighbouring states like Serbia and Montenegro had entered the war since several months alongside the Antanta against Austria-Hungary and Italy knew they would be rewarded with the Dalmatian coast but certainly also with the Albanian lands. This was probably a "moral justification" for Italy to "protect" the Albanian lands, but also a " historic excuse" that if others would extort anything from Albania after the war, why Italy could not have its part as they had always sympathized this population; after all were they defending under their umbrella what others were leaving?! If other neighbors had extorted from Albania in 1913 vital part of it, why not Italy had not a "historic" right to take something after the war as a reward for its losses?! So Albania was seen as market stuff.

Antanta's Powers encouraged Greece to enter the war and for this they suggested on November 22, 1914, the annexation of southern Albania. Greek forces, although Greece remained neutral until 1917 under the pretext of protection from Albanian chaos and under the guise of autonomist "Vorio-Epirus" motion had advanced up in Vlora and their barbarity over the local population did not have an end and could not be compared. A large part of the Albanian population of Epirus that remained within ethnic territory after 1913 was forced by Greek forces to migrate and find shelter in olives of Vlora. When Greek troops advanced into south in October 1914, Italy though, still had not entered the war, sent its troops across the Adriatic and in October 1914 landed on the rocky, uninhabited island of Sazan, intentionally emptied by the Greeks some months before. On Christmas Day they seized Vlora and its surroundings ( Jacques, 1995, p.398) Italy found many pretexts to conquer Vlora, especially the "risk" that threatened Vlora by the Greek hosts that had invaded southern Albania, under the guise of armed "Vorio-Epirus"movement, and that at the end of September 1914 were near Berat. Meanwhile the Greek government invited the government of Rome to occupy Vlora, which Italy recognized as her own area. "Greece wants to arise such a situation from the present crisis that will allow Italy to be placed in Vlora," the Greek Prime Minister Venizelos stated to the Italian representative in Athens. With this action the Athens government intended to legislate the de facto occupation of southern Albania, having first obtained the approval of Italy, as the most interested power in here, and then the other powers. But the warring powers too, in October 1914, accepted Italy's request to occupy Vlora and recognized to Greece military occupation of two regions, Gjirokastra and Korca (Albanian People's History v. III, p.157).

Not without good reason, Italian Foreign Minister Sonnino, viewed Albania as a castle that had to be occupied before becoming a serious threat, if it was conquered by Austria. With this prospect in September 2014, Sonnino had written to Prime Minister Salandra, to support the need of occupation of Sazan and Vlore, without losing time.

After the occupation of the area of Vlora, the Italian Government, in the neutral position, continued discussions with the two warring blocs to increase its broadcasting extent. Earlier at the beginning of 1915, Roma had entered into diplomatic negotiations with Vienna, which lasted until April 8, 1915 (Çami, 1987, pp.155-158). Rome demanded some concessions to Vienna and some land owned by the Austro-Hungarian. Vienna in its proposals on 27 March 1915, inter alia, sought to guard the decisions of the London Conference of 1913. However, Rome presented its extended counterproposals, on April 8, 1915, asking the Vienna besides popular spots, to "not be interested at all in Albania" (Dervishi, 2006, p. 65).

Great Britain, France and Russia were more readily in comparison with Austria-Hungary to make concessions to Italy and to give an end to it's theretofore neutrality. 


\section{The Secret Treaty of London and the Albanian Issue}

\subsection{Approval of Italian sovereignty over the region of Vlora}

Rome Government's willingness to enter to war appeared to the Antanta's Powers on March 4, 1915. Rome had done an attempt of this nature in August-September 1914. These initial steps served to the Government of Rome to understand the attitude of the Antanta's Powers for requirements that it spread as conditions to enter the war (Çami, 2007, p.60).

Antanta Powers Group, concerned to withdraw to war the Italian armed forces as soon as possible, was willing to support the requests submitted on March 4, 1915, by Italian diplomats. These requirements were ranked in 16 points. Three of them (points V, VI and VII), linked to the expansionist aims of Rome in Albania. Rome demanded that with the end of the war Italy must have sovereignty over Vlora and the province of the same name. It also demanded to have an Albanian state with very narrow borders, those of Middle "Muslim" Albania, and to offset the Albanian coast, that will not pass under the sovereignty of Italy ( Çami, 2007, f.61).

Other requirements of 4 March 1915 had to do with the passing of the provinces of the Austro-Hungarian Empire inhabited by the Italian or mixed population ethnically to Italian boundaries. It was also requested to pass the Adriatic Sea, strategically, in possession of Italy; that this could have recognized the right of preserving the balance of Mediterranean; Italy could take the part "that belonged to it" from the separation of areas of influence in the space of the Ottoman Empire and the division of colonies that Germany possessed in Africa ( Çami, 2007, p.61).

Political forces in Italy, especially the military, were paying special attention to setting the province of Vlora under Italian sovereignty, for the great strategic importance it had in the Adriatic Sea.

Driven by these circumstances, diplomats of the Antanta approved this request of Rome. And hence the wording of this request in the secret Treaty of London was no different from that developed since March 4, 1915 from Italian diplomats. "Italy will take full sovereignty over Vlora, Sazan Island and over a vast territory, sufficient to ensure the protection of these points," it was said at the VI point of the Italian requirements of 4 March 1915 ( Sonnino, p.209) . It was not made any difference at the geographical territory over which was placed the sovereignty of Italy. In the north and east it would have as limit the River of Vjose, in south it could come up to Himare, just as the italians had requested on March 4th.

What was specified further at the Treaty of 26 April 1915 was only the south border of the expansion of the hinterland of Vlora. If the document of 4 March 1915 stated that the territory will be extended south "nearly in Himare" on the Treaty of 26 April was determined that this territory will be reached "nearly up to the northern border district of Himara"( Çami, 2007, p.62). Himara was excluded from the geographical space that would pass under the sovereignty of Italy. This allocation was requested by the British representative, E. Gray, who wanted to pass to Greece the entire Himara ( Sonnino, p.412).

Placement of Italian sovereignty over the region of Vlora was part of the requirements of Rome for the possession of the Adriatic Sea, possession which then had a more anti Austrian character than antislave. Consequently, none of the three Antanta's Powers did not oppose it. The Russian Empire itself acknowledged, though not without warning. Russia's representatives were precisely those adopting Rome's demand on Vlora related (more than their French and English counterpart), with other requirements of Italy in the eastern Adriatic coast, especially in the Dalmatian coast. Russian diplomacy was ready to accept the passage of Vlora province under the sovereignty of Italy with a view to Roma to give up or to limit its claims to Dalmatia, claims that conflicted with the plans of the Belgrade government. N. Pashiçit's government aimed to unite all territories of the Southern Slavs who were under Austro-Hungary into a single Yugoslav state, including Dalmatia, inhabited mainly by Croat ( Çami, 2007, p.61).

These circumstances prompted the Foreign Minister of the Russian Empire, S. Sazonovin, to value the the geostrategic importance that had Vlora and Pola on the Adriatic (from Italy) and undervalued the importance of the claims of Rome in Dalmatia. Unlike these assessments of Russian Minister of Foreign Affairs for Vlora, his Italian counterpart, S. Sonnino, in its diplomatic struggle disregarded the importance of Vlora "We can not acknowledge that Vlora really closes Adriatic", he claimed to the representatives of the allied powers of the future (especially those of Russia), when he had to undervalue the geostrategic importance of Vlora ( Çami, 2007, p.64) in order to raise the weight of demands that were rejected elsewhere for Italy.

After the discussion and approval of the request for transfer of Vlora and its province under Italian sovereignty was passed to review another request of the Italian diplomacy, in that for the establishment of the Albanian state and on its borders. 


\subsection{The discussion on the borders of the new Albanian state}

Rome government's demands for the existence of the Albanian state ranked in paragraph $\mathrm{V}$ of the Italian requests of 4 March and it remained the same even at the Treaty of 26 April 1915. The document of March 4 declared: "The port of Durres belonged to independent Muslim state of Middle Albania". This was one of the requirements that sparked many discussions and debates" (Sonnino, dok.133, p.209).

In order to support the need for existence of this state, Rome diplomacy elaborated and "argumented" if in case against this request will react representatives of the Antanta's Powers. And there were reactions. Italian ambassador, G. Imperiali, predicted these in London. At first he had thought it would arouse objections only Italian requirements for the Austro-Hungarian territories inhabited by Slavs (Sonnino, dok.144, 175), while on March 13, 1915 he wrote to Rome: "I do not know why I have the impression that on this point", ie the existence of the Albanian state, "we may find resistance from the Antanta, which I think prefers more to satisfy the Serbian aspirations on Durres" (Sonnino, dok. 180).

It would be the Italian ambassador in the British capital the one that supported the claim of Rome; he presented to his interlocutors "arguments" of Italian diplomacy. What stands out among them is the rivalry of Italy for sharing Albania with Balkan neighbors especially the Italian-Serbian rivalry to divide the Middle Albania. In this case the diplomacy of Rome put the veil of "protector" for peace and Albanian Muslim population. The presence of this state, claimed Imperiali, will avoid "uprisings, fears and risks of continuing conflict between Christian elements and Muslim populations. For years Italy has always taken from Albania, particularly against the Muslim, the side of the defense of its political and religious independence and we can not stop feeling the moral duty of protecting these populations", stated Ambassador of Rome (Çami, 2007, p.65).

After this human "role" was passed in the real motives that had pushed Rome to demand the existence of an Albanian state on its Middle Albania borders. His presence "intended to serve as a buffer zone between Vlora (the surrounding territories), on the one hand, and Serbia, on the other hand, and to prevent that our possession of Vlora to be surrounded by Greece ( Sonnino, dok.183.), Rome's diplomat stressed.

According to Rome's Government, Albanian "Muslim" state should play, therefore, the role of "defender" for Italian possession of Vlore, in the first place. However the Italian request for the presence of this Albanian state conflicted with the plans of the Antanta's Powers, for which state's territories should serve to satisfy the appetites of Italy but also of all neighboring countries. It even became an obstacle for combinations in a wider plane. It would not only prevent the emergence of Serbia in the Adriatic Sea (via Durres), but also the Antanta's powers would not be able to access the Albanian state lands to compensate Serbia and Greece for concessions that these would have make for Bulgaria in Macedonia, in order to recreate the Balkan alliance of 1912- 1913 (Çami, 2007, p.66). In such circumstances, the Antanta's diplomats were put in a difficult position, especially S. Sazonovi, to find the convenient solution. Russian Tsarist Empire Minister was against the creation of an Albanian state in the Middle Albania. "Albania must be devided between Greece and Serbia" (Çami, 2007, pp.66-67) he stated, on March 12, 1915, to the ambassadors of France and England in the Russian capital.

Meanwhile, Italy's readiness to enter the war brought the problem of redistricting Macedonia in the second plan in relation to the allocation of Dalmatia between Italy and Serbia. In this case Italy should definitely be satisfied, in order to withdraw it at war, but without desperating Serbia, which fought for months alongside the Antanta's Powers. In this way they added efforts to flatten the Italian-Serbian rivalry for Dalmatia as well as for Albania (L'intervento dell'Italia nei documenti segreti dell Intesa, dok.91, 1925).

These efforts for the existence or not of the Albanian state, continued until the end of March with mutual concessions. Approval of the Italian request for the establishment of Albanian state was followed by Italy's resignition from the requirement of southern Dalmatia. This part of Dalmatia (which starts north of the port of Split and continues along the coast up the Drin river spill) would be passed to Serbia and Montenegro (Sonnino, dok.215, 220, 221).

Regarding the so-called Albanian state, in point $\mathrm{V}$ of the Treaty of London it was declared: "The port of Durres belongs to the independent Muslim state of Albania" (Çami, 2007, p.67). After the request for the existence of "Albanian state" in the Middle Albania and after the aknowledgment of this request from prospective allies of Italy, Rome came up with a new goal. It requested the establishment of this "state" under the control or under the Italian protectorate. And they achieved this goal without any difficulty (Çami, 2007, p.68).

\section{3 "The new Albanian state" under the Italian protectorate}

The new request for the establishment of the Albanian state under the protectorate of Italian diplomacy was followed by 
new transactions. After quiting from Southern Dalmatia in favor of Serbia's, the diplomacy of Rome agreed to pass to Belgrade the the Dalmatian islands, for the annexation of which Italy had insisted until then (Sonnino, dok.250, 253), considering these "new concessions in favor of Serbia" and demanding compensation the setting of "Albanian state" under control or Italian protectorate in the form of his representation for the outside world. "In exchange for these omissions we request for Italy only ... diplomatic representation of the small Albanian Muslim state, which will not have enough funds to keep its missions ", S. Sonnino declared to his ambassador in London, Imperial, on April 14. This new request was not opposed by any of the partners of Italy (Sonnino, dok.253), pushed by political circumstances of the time, even Russia admitted it. Unable averting Italian expansion from the Balkan, the attention of Russian diplomacy focused on the elimination of this expansion on the Slavic lands. And they achieved this, although partly with the compensation for Italy on their claims in Albania. Therefore the request for the protectorate did not became an obstacle for the completion of negotiations and the signing of the Secret Treaty of London on April 26, 1915 (Çami, 2007, p.69). In this Treaty Italy's request of 14 April was included in point VII of the Treaty and was formulated thus: "Italy will be charged to represent the state of Albania in its relations with the outside world" (Sonnino, p.256).

Accepting this request constituted a new diplomatic success for Rome. Italy replaced with its control the international control of the six powers, situated on the Albanian state in 1913. Rome's government would be able to avert the current interventions of the external forces in the future Albanian "State", especially the neighboring Balkan monarchies, and would supervise closely the activity of Albanian political leaders. Understandably if the Antanta's powers would win the war and if the protectorate would be put into life (Çami, 2007, p.69).

T. Tittoni, then ambassador of Rome in France, noted this Italy's success. "After Sazonov accepted our last proposal for Dalmatia and Albania's diplomatic representation, which Sazonovi termed as a really Italian protectorate, my impression is that we have achieved a real success," he wrote to his boss, S. Sonninos, on April 17. "For us it is more important that the future state Albania to be a little smaller, but completely under our influence - went further Tittoni "(Sonnino, dok.267). The aim and essence of Italian expansionist politics to the Albanian issue was clearly expressed in these words of Tittoni.

\subsection{The secret treaty of London and the Peace Conference}

If during the war The secret Treaty of London suffered substantial blow, after the war it was "buried" definitely. Its end came as a result of two different but convergent factors: a) the contradictions of major powers and b) the resistance struggle of the Albanian people (Puto, 1965, p.22) .

A. United States of America, which were displaying a tendency to come out of traditional "isolationism" and to play the role of arbiter in world affairs, they refused to recognize agreements concluded without their participation. The US government, through President Wilson declared in April 1919: "When Italy entered the war, they went on the basis of an agreement specified but secret affiliated with Great Britain and France, this agreement is now known by the name" the Treaty of London ". Since then circumstances have completely changed. Many other countries, small and large, went to war without having any idea of the secret agreement ... ". Except that "points of support which were given to Italy in the eastern Adriatic coast were intended to give them the opportunity to provide its coast by a maritime attack of Austro-Hungary" (Puto, 1965, p.22) By now, Austro-Hungary no longer existed.

On the other side, Italy at the Peace Conference asked not only the implementation of the Treaty of London, but also Fiuma, which was not foreseen in 1915. Its allies were not ready to give even what they had promised. Their wore their purely political motives with legal arguments, putting in doubt the validity of the Treaty of 1915. Italian delegation at the Conference of Paris, in June 1919, was in front of a statement of L'ovd-George and Clemenceau, through through which they announce that the Treaty of 1915 could serve only as a preliminary basis of further discussion, but can not be regarded as a perfect agreement, with legally binding character, because Italy had "violated obligations arising from art.2 of the Treaty by not immediately declaring war on Germany". In addition, another "partial" argument which the allies used was that Italy had withdrawn himself from the Treaty of London with the proclamation of Gjirokastra June 1917 (Puto, 1965, p.23), where Italy as the counterweight of Austro-Hungary reasserted the independence of the Albanian state, under the protection of Italy.

It is true that following the diplomatic Anglo-Franco efforts Americans abandoned the "legal principality" and virtually recognized main provisions of the Treaty of 1915 on Albania memorandum of 9 December 1919 and the 14 January 1920 agreement that predicted a new division of the country. But the knot of contradictions was 
not resolved. To the old American opposition was added the unpredicted oppose of Yugoslav, too. Assessing the presence of Italy in the Balkan Peninsula as a risk that could not be counterbalanced by the benefits of Albanian division, Yugoslavia decided to come out in favor of the decisions of 1913, so against the implementation of the Treaty of London, at least in the version of 1915 (Puto, 1965, p.23).

In the prememorien of Yugoslav delegation at the Peace Conference, addressed to Clemenceau's on January 14, 1920 it was stated: As for Albania, the delegation of the Serbian, Croats and Slovenes Kingdom notes again .... That the best solution would be to entrust the Albanian governance, as it was established by the Conference of Ambassadors in London in 1913, to an autonomous government without the intervention of any foreign state" (Quoted by the Memorandum of the Albanian delegation at the League of Nations, dt. 22 XI.1920, në AQH-DMJ, Folder "Acceptance of Albania to the League of Nations"). The agrrement on the division of Albania was all compromised.

B. The feeling of anger that seized the broadest masses of the people from the new plans for dividing Albania, became a cause for a powerful patriotic movement on a very high national basis. As the climax of this movement was Lushnja Congress in January-February 1920 and the War of Vlora, in June-August 1920. Assembly of Lushnja in January 1920 approved that "Albanians are ready to make any sacrifice until the last drop of their blood against any decision that could jeopardize their independence and national integrity" (Puto, 1965, p.24).

Italy, having proved themselves the strength of resistance of the Albanian people in the war of Vlora, was forced to sign the " Preliminary Protocol» of Tirana on 2 August 1920 in Article 2 which stated:« The Italian government, to provide proof of its feelings of respect for Albanian sovereignty over Vlora and for territorial Albanian integrity would withdraw Italian troops who are deployed in Vlora and its coast, as well as in the rest of Albania " (Puto, 1965, p.24).

With this open denunciation of the Italian party, as a party expecting the major benefits, the whole affair of the secret Treaty of London, with all zigzags and numerous vicissitudes, should be considered closed once and for all. Any further discussion regarding its validity was futile and meaningless.

\section{Conclusions}

Albanian nation being between two of the greatest europian ancian civilizations of Greek and Latin, could not be insignificant in the context of European culture and history. Our southern greek neighbors have understood the vitality of this nation with the contribution of our compatriots in the formation and development of the Greek state, ranging from Arvanites and the top leaders of the Greek Revolution. The overseas Italy has historically recognized the Albanian contribution to European history, with the great Skanderbeg, rider of Western civilization. Historical moments, with political stir of the time like the First World War, must not be so dramatically influencing the Italian diplomacy, as to go to an extreme position of forgetfulness of a nation as were the Albanians. Indeed Albanian nation was not telling yet the signs of recovery, at the beginning of the XX century, but Italy had to take into account agony of centuries that the Ottoman Empire imposed to Albanians, as revenge against our hero Scanderbeg who hampered their plans on European conquest. The secret Treaty of London showed that when a country's political class as was Italy, loses the sense of understanding while facing pressures, but historical forgetfulness too, becomes a imperialist class with consequences against its nation. This treaty once again brought to light the hidden intentions of Albania's neighbors, but also mobilized Albanians to fend their country's fate. The failure of this treaty also due to Albanian resistance to the predatory aims of the neighbours showed that when you fight for a right cause the support delays but does not forget. Despite some negative historical facts, Albanians continue to see to Italy a fraternal neighbor, a support on their way to European integration.

\section{References}

Albanian issue in international acts (1867-1912), V. I, d. nr.30

Albanian People's History v. III

Andelman, David A. (2008). Wrecked peace; Versajë 1919 and the price we pay today. Tirana: Toena

Çami, M. (2007). Albania in the course of history (1912-1924). Tirana: Onufri

Çami, M. (1987). Albania in international relations 1914-1918, Tirana

Dervishi, K. (2006). Albanian State History 1912-2005. Tirana

Jacques, Edwin. (1995). ALBANIANS history of the Albanian people from antiquity to the present day. The Feather Card 
Memorandum of the Albanian delegation at the League of Nations, dt. 22 XI.1920, në AQH-DMJ, Folder "Acceptance of Albania to the League of Nations"

Puto, A. (1965). Some legal problem of Albanian independence, "Historical Studies", Nr.1, Tirana: Mihal Duri

Procacci, G. (2000). Historia e italianeve. Tirana: Toena \& Shtepia e Librit

Sonnino, S. (1974). Carteggio, 1914-1916. Bari 